\title{
JAK UCZYĆ PRAWA OCHRONY ŚRODOWISKA? DOŚWIADCZENIA POLSKIE, CZESKIE I SŁOWACKIE
}

\section{HOW TO TEACH ENVIRONMENTAL LAW? POLISH, CZECH AND SLOVAK EXPERIENCES}

\section{STRESZCZENIE}

Artykuł poświęcony jest dydaktyce prawa ochrony środowiska. Nie tylko w Polsce ale także w Czechach i na Słowacji. Przyświeca mu założenie, że nawet jeśli prawo ochrony środowiska nie jest odrębna gałęzią prawa, to na pewno jest dyscypliną dydaktyczną i przedmiotem badan naukowych o rosnącym znaczeniu. Autorzy dokonują przeglądu podstawowych podręczników, zarówno starszych jak i nowszych. Ponadto próbują odpowiedzieć na pytanie jakie funkcje ma spełniać

* Doktor nauk prawnych, Zakład Prawa Ochrony Środowiska Instytutu Nauk Prawnych PAN, Wrocław.

** Prof. zw. dr hab., Zakład Prawa Ochrony Środowiska Instytutu Nauk Prawnych PAN, Wrocław. 
dobry podręcznik, i co przede wszystkim powinien zrozumieć student poznający tę dziedzinę prawa.

\section{Słowa kluczowe}

Prawo ochrony środowiska, podręcznik, dydaktyka, nauka, cel prawa ochrony środowiska.

\section{ABSTRACT}

Article is devoted to teaching of environmental law in Poland, Czech Republic and Slovakia. Even if the environmental law is not a separate branch of law, it certainly is a discipline of teaching and scientific research subject of increasing importance. The authors review the basic textbooks, both older and newer. In addition, the authors try to answer the question, what features to meet a good book, and which above all should understand the student knowing this area of law.

\section{Keywords}

Environmental law, teaching, textbook, science, branch of law, objective of environmental law.

\section{UWAGI WSTĘPNE}

Niniejsze opracowanie poświęcamy dydaktyce prawa ochrony środowiska, rozumiejąc przez to metody nauczania i uczenia się tej dziedziny prawa. Nie angażujemy się w dyskusję na temat statusu prawa ochrony środowiska jako odrębnej gałęzi prawa $^{2}$, aczkolwiek zaznaczamy, iż prawo ochrony środowiska

1 W języku polskim dydaktyka to nauka o metodach nauczania i uczenia się (Uniwersalny słownik języka polskiego, pod red. S. Dubisza, Warszawa 2003).

2 Zob. np. M. Górski, Prawo ochrony środowiska jako odrębna gałą́z prawa (w pogladach doktryny polskiej i niemieckiej), „Studia Prawno-Ekonomiczne”, t. XLVIII, Łódź 1993, s. 57-70. 
niewątpliwie jest wyodrębnioną dziedziną (przedmiotem) nauki i dydaktyki. Na boku pozostawiamy refleksję nad rozwojem i stanem nauki prawa ochrony środowiska - uznając wszakże taką analizę za uzasadniona i potrzebną - dokonaliśmy jej w innym miejscu ${ }^{3}$. Czynimy na wstępie dwa założenia. Pierwsze jest takie, iż ochrona środowiska jest działem regulacji prawnej o stale wzrastającym polu regulacji i jednocześnie rozwijającym się kierunkiem badań naukowych. W związku z tym wyodrębnienie, nawet umowne i o cechach podziału dowolnego, stwarza większe możliwości rozwoju dydaktyki jak i specjalizacji zawodowej w praktyce prawniczej oraz tworzenia struktur organizacyjnych obsługujących to prawo ${ }^{4}$.

Założenie drugie jest takie, że rozwojowi i doskonaleniu dydaktyki sprzyja rozwój nauki, co sprawia, że wcześniejsze, właśnie doktrynie poświęcone opracowanie, z niniejszym pozostaje w racjonalnym i bliskim związku. Co więcej, rozróżnienie nauki od nauczania, a co za tym idzie, dzieła naukowego od podręcznika, nie zawsze jest możliwe. Dlatego zakładamy, że poświęcone szczegółowym zagadnieniom monografie mogą (choć nie muszą!) być pożyteczne w dydaktyce, a zasięg dobrego podręcznika nie musi ograniczać się tylko do uczących się prawa studentów. Ponadto jedna z konkluzji wcześniejszego artykułu zawierała zarzut słabości badań porównawczych w zakresie prawnej ochrony środowiska - dlatego w rozważaniach nad obrazem nauczania prawa ochrony środowiska chcemy sięgnąć do podręczników i metod stosowanych za południową granicą Rzeczypospolitej Polskiej.

Prawo ochrony środowiska jest więc nie tylko frapującym przedmiotem refleksji naukowej, lecz także dziedziną dydaktyczną na wydziałach prawa szkół wyższych. Przedmiotem naszego szkicu będzie poszukiwanie odpowiedzi na pytanie, z jakich podręczników i innych pomocy dydaktycznych korzystają studenci prawa oraz próba oceny, czy i w jakim stopniu przyczyniają się

3 A. Habuda, W. Radecki, Stan polskiej nauki prawa ochrony środowiska w 40 lat po raporcie U Thanta, „Studia Prawnicze” 2009, nr 3.

4 J. Sommer, Efektywność prawa ochrony środowiska i jej uwarunkowaniaproblemy udatności jego struktury, Wrocław 2005, s. 126. 
one do uzyskania przez absolwenta wydziału prawa odpowiedniej wiedzy i umiejętności posługiwania się regulacjami należącymi do prawa ochrony środowiska. Rozważania poprowadzimy biorąc pod uwagę z jednej strony Polskę, z drugiej Republikę Czeską i Republikę Słowacką. Nie jest naszym zamiarem prezentacja całego dorobku dydaktycznego tych trzech państw, co ze względu na ogrom materiału byłoby niemożliwe, ograniczymy się przeto do kwestii podstawowych dotyczących podręczników $\mathrm{i}$ innych pomocy dydaktycznych.

W myśl rozporządzenia Ministra Nauki i Szkolnictwa Wyższego w sprawie standardów kształcenia dla poszczególnych kierunków i poziomów kształcenia, a także trybu tworzenia i warunków, jakie musi spełniać uczelnia, by prowadzić studia międzykierunkowe oraz makrokierunki ${ }^{5}$, prawo ochrony środowiska nie mieści się ani w grupie treści podstawowych ani w grupie treści kierunkowych (załącznik nr 85 określający standardy kształcenia dla kierunku Prawo). Nie oznacza to oczywiście braku podstaw dla nauczania tej dziedziny prawa albowiem w punkcie V. 3 rozporządzenia stanowi się, że „programy nauczania powinny przewidywać zajęcia z zakresu prawa ochrony środowiska”. Prawo ochrony środowiska jest więc zasadniczo przedmiotem wykładanym w ramach studiów prawniczych w Polsce.

Dynamiczny rozwój dydaktyki prawa ochrony środowiska następuje właściwie od początku XXI w., co potwierdza fakt, iż od tamtego czasu zaczęło ukazywać się znacząco więcej opracowań o charakterze podręcznikowym. Oczywiście podręczniki, czy opracowania o podobnym charakterze ukazywały się już wcześniej, jednak było ich znacząco mniej. Trzeba tu wymienić prace Jana Bocia ${ }^{6}$, Ludwika Jastrzęb-

5 Dz. U. z 2007 r. Nr 164, poz. 1166 ze zm.; rozporządzenie to zostało uchylone z dniem 1 października 2011 r. ustawą z dnia 18 marca 2011 r. o zmianie ustawy - Prawo o szkolnictwie wyższym, ustawy o stopniach naukowych i tytule naukowym oraz o stopniach i tytule w zakresie sztuki oraz o zmianie niektórych innych ustaw, Dz. U. z 2011 r. Nr 84, poz. 455 ze zm.

6 J. Boć, Zagadnienia prawne ochrony środowiska naturalnego, Wrocław 1979; J. Boć, E. Samborska-Boć, Ochrona środowiska. Zagadnienia prawne i ekonomiczne, Wrocław 1989; J. Boć, K. Nowacki, E. Samborska-Boć, Ochrona środowiska, Wrocław 2004. 
skiego $^{7}$, Ryszarda Paczuskiego ${ }^{8}$, Janiny Ciechanowicz ${ }^{9}$ oraz interdyscyplinarną pracę Kazimierza Górki, Bazylego Poskrobko, Wojciecha Radeckiego ${ }^{10}$. Tę ostatnią pozycję trudno określić jako podręcznik prawa ochrony środowiska, bowiem w zasadzie tylko jeden jej rozdział (autorstwa W. Radeckiego) poświęcony jest tej dziedzinie. Pozostałe traktują o problemach społecznych, politycznych i ekonomicznych związanych z ochrona środowiska. Można więc powiedzieć, że jest to podręcznik ochrony środowiska w ujęciu nauk społeczno-ekonomicznych, w tym przedstawiający prawne podstawy ochrony środowiska. Pozycję tę sytuujemy wśród „starszych” także ze względu na to, że rozdział poświecony prawu oparty jest na nieobowiązującej ustawie o ochronie i kształtowaniu środowiska z 1980 r.

Dlaczego akurat przełom XX i XXI w. staje się zauważalną granicą w rozwoju wydawniczym dydaktyki prawa ochrony środowiska? Myślimy, że bezpośrednio przyczyniły się do tego dwa wydarzenia: uchwalenie i wejście w życie Konstytucji RP z 1997 r. wysoko sytuującej ochronę środowiska wśród wartości konstytucyjnych ${ }^{11}$ oraz uchwalenie i wejście w życie nowego prawa o ochronie środowiska (ustawa Prawo ochrony środowiska z dnia 27 kwietnia 2001 r.). Od tego czasu opracowań podręcznikowych do nauczania prawa ochrony środowiska jest znacząco więcej. Swoje podręczniki przygotowały i wydały ośrodki

7 L. Jastrzębski, Ochrona prawna przyrody i środowiska $w$ PRL. Zagadnienia administracyjne, Warszawa 1979; L. Jastrzębski, Ochrona środowiska w PRL. Zagadnienia administracyjne, Warszawa 1983; L. Jastrzębski, Prawo ochrony środowiska w Polsce, Warszawa 1990.

8 R. Paczuski, System prawno-organizacyjny ochrony środowiska w PRL, Toruń 1977; R. Paczuski, Prawo ochrony środowiska, Bydgoszcz 1994 (kolejne wydania w r. 1996 i 2000).

9 J. Ciechanowicz, Prawo ochrony środowiska, Koszalin 1995.

10 K. Górka, B. Poskrobko, W. Radecki. Ochrona środowiska. Problemy społeczne, ekonomiczne i prawne, Warszawa 2001; poprzednie wydania: 1991, 1995, 1998.

11 Aż pięć miejsc w Konstytucji, bezpośrednio odnoszących się do ochrony środowiska, na czele z art. 5 zaliczającym ochronę środowiska do obowiązków władz publicznych bezspornie potwierdza, iż w obecnej ustawie zasadniczej ranga ochrony środowiska jest wysoka. 
uniwersyteckie: gdański ${ }^{12}$, śląski ${ }^{13}$, łódzki ${ }^{14}$, toruński ${ }^{15}$, olsztyński $^{16} \mathrm{i}$ lubelski ${ }^{17}$ (do tego dochodzi już wykazany i kontynuowany podręcznik autorów wrocławskiego ośrodka uniwersyteckiego), a także wrocławskie Centrum Prawa Ekologicznego ${ }^{18}$. W tym samym nurcie można umieścić opracowanie poświęcone ochronie przyrody ${ }^{19}$, a także zarysowanie podstaw prawa ochrony środowiska przeznaczone dla administracji ${ }^{20}$. Trzeba także zaznaczyć uaktualniony i inaczej zatytułowany podręcznik Ryszarda Paczuskiego $^{21}$, wydany w Bydgoszczy w $2008 \mathrm{r}$.

Obiektywna konstatacja jest taka, iż w ciągu 10 lat (w przybliżeniu okres 2000-2010) wydano więcej podręczników (pozycji o podobnym charakterze), nie licząc wznowień i kolejnych wydań, niż w całej poprzedzającej historii wydawnictw dydaktycznych (od lat 70.). Podchodzimy z rezerwą do oceny i podsumowań dorobku wydawniczego podług miary matematycznej, nadto obecnie nieznane są niektóre ograniczenia wydawnicze istotne w minionym ustroju. Niewątpliwie jednak zjawisko roz-

12 Z. Brodecki, E. Gończ, D. Lost-Siemińska, S. Makowska, F. Pankau, D. Pyć, A. Tyszecki, Ochrona środowiska. Acquis communautaire, Warszawa 2005.

13 A. Lipiński, Prawne podstawy ochrony środowiska, Kraków 2002, kolejne wydania w latach 2004, 2005, 2007, ostatnie: Warszawa 2010.

${ }_{14}$ M. Górski, J. S. Kierzkowska (red.), Prawo ochrony środowiska, Bydgoszcz 2006. Opracowanie po trzech latach powtórzone w nieco zmienionej formule: M. Górski (red.), A. Barczak, D. Jakubowska, A. Jaworowicz-Rudolf, A. Kaźmierska-Patrzyczna, J. S. Kierzkowska, P. Korzeniowski, J. Miłkowska, Prawo ochrony środowiska, Warszawa 2009.

15 B. Wierzbowski, B. Rakoczy, Podstawy prawa ochrony środowiska, Warszawa 2004, kolejne wydania w latach 2005, 2007 i 2010.

16 U. Szymańska, E. Zębek, Prawo i ochrona środowiska - prawne, ekonomiczne, ekologiczne i techniczne aspekty ochrony środowiska naturalnego, Olsztyn 2008.

17 J. Stelmasiak (red.), Prawo ochrony środowiska, Lublin 2009; wyd. II Lublin 2010.

18 M. Bar, J. Jendrośka, Prawo ochrony środowiska. Podręcznik, Wrocław 2005.

19 J. Ciechanowicz - McLean (red.), K. Biernat, P. Mierzejewski, D. Trzcińska, Polskie prawo ochrony przyrody, Warszawa 2006.

20 Z. Bukowski, Podstawy prawa ochrony środowiska dla administracji, Włocławek 2005.

21 R. Paczuski, Ochrona środowiska. Zarys wykładu, Bydgoszcz 2008. 
woju wydawnictw dydaktycznych jest odpowiedzią na rozwój dydaktyki (nauczania) i potrzeb w tym zakresie.

\section{POLSKA}

Jak są skonstruowane i do czego się odnoszą podręczniki prawa ochrony środowiska? Poniżej przedstawiamy strukturę kilku popularnych i dostępnych podręczników. Rozpoczynamy do wydawnictwa wrocławskiego Centrum Prawa Ekologicznego, bowiem już w tytule autorzy nazywają swoje opracowanie podręcznikiem. To powód pierwszeństwa tej pozycji.

Podręcznik M. Bar i J. Jendrośki podzielony jest na 4 części:

I. Część ogólna (podstawowe pojęcia, koncepcje, zasady, rozwój, instrumenty prawne ochrony środowiska, dostęp do informacji o środowisku, oceny oddziaływania na środowisko).

II. Międzynarodowe prawo ochrony środowiska (rozwój, umowy międzynarodowe w systemie prawa ochrony środowiska, kontrola i przestrzeganie, charakterystyka wybranych konwencji międzynarodowych).

III. Wspólnotowe prawo ochrony środowiska (rozwój, źródła, zasady ogólne, programy działania, kontrola przestrzegania i egzekwowanie, instytucje UE zaangażowane w ochronę środowiska, gromadzenie i udostępnianie informacji o środowisku, udział społeczeństwa, oceny oddziaływania, ekoaudyt i ekologiczne znakowanie, zintegrowane zapobieganie i kontrola zanieczyszczeń, poważne awarie, ochrona powietrza, ochrona wód, ochrona powierzchni ziemi, ochrona przed hałasem, ochrona promieniowaniem, konserwatorska ochrona przyrody, kontrola chemikaliów, kontrola GMO, rolnictwo ekologiczne, odpowiedzialność za szkody w środowisku).

IV. Polskie prawo ochrony środowiska (rozwój, system prawa ochrony środowiska, ochrona środowiska w Konstytucji, zasady ogólne, organizacja administracji, gromadzenie i udostępnianie informacji o środowisku, polityka eko- 
logiczna i programy ochrony środowiska, udział społeczeństwa, oceny oddziaływania, ekoaudyt i ekologiczne znakowanie, ochrona zasobów środowiska, prawo emisyjne, ograniczenia sposobów korzystania z nieruchomości w związku z ochrona środowiska, zintegrowane zapobieganie i kontrola zanieczyszczeń, poważne awarie, ochrona powietrza, ochrona wód i gospodarka wodna, gospodarowanie odpadami ochrona powierzchni ziemi, ochrona przed hałasem, ochrona przed promieniowaniem, konserwatorska ochrona przyrody, kontrola chemikaliów, kontrola GMO, rolnictwo ekologiczne, ekonomiczne instrumenty ochrony środowiska, odpowiedzialność w ochronie środowiska).

Czyli najpierw oznaczamy obszar zainteresowania przedstawiając podstawowe pojęcia, genezę, najważniejsze instrumenty, następnie opisujemy rozwój międzynarodowego prawa ochrony środowiska opierając się na kluczowych konwencjach je wyznaczających, dalej zaś uczymy prawa wspólnotowego i polskiego, zarówno ukazując to co mieści się w tzw. części ogólnej, jak i zagadnienia bardziej „sektorowe”. części:

Praca pod redakcją Z. Brodeckiego podzielona jest na trzy

I. Zrozumieć Unię Europejską;

II. Porządek prawny Unii Europejskiej;

III. Porządek prawny Rzeczypospolitej Polskiej.

Cześć pierwsza poświęcona jest miejscu ochrony środowiska wśród ogółu działań UE. W części drugiej omawia się kolejno: źródła prawa UE w zakresie ochrony środowiska, ogólne zagadnienia prawnoustrojowe $-\mathrm{w}$ tym przede wszystkim zasady prawa ochrony środowiska, prawo w ujęciu horyzontalnym (oceny oddziaływania i dostęp do informacji), ochronę składników środowiska, kwestię działalności gospodarczej wobec ochrony środowiska, oraz ochronę przyrody. Natomiast część trzecia to rozdziały poświęcone polityce ekologicznej i zarządzaniu środowiskiem, ogólnym zagadnieniom prawnoustrojowym (przede wszystkim zasady prawa ochrony środowiska), ochronie składników środowiska, działalności gospodarczej w kontekście ochro2/2011 ny środowiska oraz ochronie przyrody. Ostatni rozdział części 
trzeciej to omówienie przejściowych rozwiązań wynikających z Traktatu Akcesyjnego.

Systematyka podręcznika A. Lipińskiego (wydanie z 2005 r.) jest następująca:

1. Wprowadzenie do prawnej ochrony środowiska,

2. Dostęp do informacji o środowisku,

3. Niektóre postępowania dotyczące ochrony środowiska,

4. Planowanie i zagospodarowanie przestrzenne jako instrument ochrony środowiska,

5. Prawne instrumenty ochrony powierzchni ziemi,

6. Prawne problemy gospodarki wodnej,

7. Gospodarowanie geologicznymi zasobami środowiska,

8. Prawna ochrona roślin i zwierząt,

9. Prawna ochrona przyrodniczych wartości środowiska,

10. Niektóre zagadnienia prawa emisyjnego,

11. Postępowanie $z$ odpadami oraz utrzymanie czystości (porządku),

12. Stany szczególnego zagrożenia,

13. Prawno - finansowe instrumenty ochrony środowiska,

14. Finansowanie ochrony środowiska,

15. Niektóre rodzaje odpowiedzialności,

16. Zadania niektórych organów administracji publicznej oraz organizacji społecznych w zakresie ochrony środowiska.

W podręczniku pod red. J. Stelmasiaka przyjęto podział na dwie części: pierwszą obejmująca zagadnienia ogólne prawa ochrony środowiska (poszczególne rozdziały poświęcono ogólnej charakterystyce podstaw prawnych ochrony środowiska w RP, zasadom ogólnym, organom, orzecznictwu sądów i trybunałów, ocenie oddziaływania na środowisko, odpowiedzialności administracyjnej, cywilnej i karnej w ochronie środowiska oraz instrumentom finansowo - prawnym w ochronie środowiska) oraz drugą - zatytułowaną „Regulacje sektorowe prawa ochrony środowiska". W części drugiej mowa jest o ochronie powietrza, ochronie wód, ochronie powierzchni ziemi, ochronie przed polami elektromagnetycznymi, relacji prawa geologicznego i górniczego do ochrony środowiska, prawnej regulacji gospodarki odpadami, prawnych formach ochrony przyrody, miejscu ochrony zabytków nieruchomych $\mathrm{w}$ ramach ochrony przyrody oraz 
o ochronie środowiska w planowaniu przestrzennym i w prawie budowlanym.

Z kolei R. Paczuski w swoim opracowaniu z roku 2008 wyodrębnia dwa podstawowe działy: pierwszy - wprowadzenie do problematyki prawnej ochrony środowiska, drugi - polskie prawo ochrony środowiska - zarys części ogólnej. Dział I tworzą dwa rozdziały (Ochrona środowiska w świetle niektórych podstawowych dokumentów i strategii działania ONZ oraz Rola polityki i prawa $\mathrm{w}$ zarządzaniu ochrona środowiska, z uwzględnieniem naukowych podstaw tego zarządzania, opartych na dokumentach ONZ) natomiast dział II to trzy rozdziały (Prawo ochrony środowiska, jego cechy, struktura i niektóre podstawowe ustalenia terminologiczne, Główne składniki obowiązującego porządku prawnego w dziedzinie ochrony środowiska ze szczególnym uwzględnieniem kompleksowej regulacji prawnej, Uwagi na temat ukształtowanego i obowiązującego obecnie polskiego prawa ochrony środowiska oraz wynikające $\mathrm{z}$ nich wnioski natury metodycznej co do organizacji procesu dydaktycznego w zakresie ochrony środowiska, opartej na podstawach prawnych). Najnowsze wydanie podręcznika R. Paczuskiego jest zmodyfikowaną i skróconą wersja podręcznika wcześniejszego (ostatnie wydanie z 2000 r.), którego budowa opierała się na czterech działach: 1) wprowadzenie do problematyki prawnej ochrony środowiska (rola polityki i prawa w ochronie środowiska oraz nowe gałęzie wiedzy służące tej ochronie, ewolucja pojęć i poglądów na temat ochrony środowiska w Polsce, prawo ochrony środowiska UE i proces przystosowywania polskiego prawa do standardów UE, 2) prawo ochrony środowiska - zarys części ogólnej (cechy, struktura, podstawowe zasady i funkcje prawa ochrony środowiska, prawnoustrojowe podstawy ochrony środowiska w Polsce, 3) prawo ochrony środowiska - zarys części szczegółowej (aspekt gospodarczy ochrony prawnej środowiska, gospodarowanie powierzchnią ziemi i zasobami surowców mineralnych, ochrona gruntów rolnych i leśnych oraz gospodarowanie zasobami lasów i zwierzyny, gospodarowanie zasobami wód śródlądowych i środowiska morskiego, racjonalne gospodarowanie zasobami świata roślinnego i zwierzęcego, gospodarowanie 2/2011 odpadami oraz ochrona zdrowia ludzkiego i środowiska przed 
szkodliwymi uciążliwościami odpadów, aspekt sanitarny ochrony prawnej środowiska, ochrona środowiska przed zanieczyszczeniem, zagadnienia ochrony środowiska przed substancjami chemicznymi, ochrona środowiska przed hałasem i wibracjami, ochrona środowiska przed promieniowaniem, aspekt zachowawczy ochrony prawnej środowiska, parki narodowe i inne obszary prawem chronione tworzące krajowy system obszarów chronionych, ogrody zabytkowe i inne obiekty środowiska uznane za dobro kultury - ogrody botaniczne i zoologiczne, ochrona gatunkowa roślin i zwierząt, prawne podstawy humanitarnej ochrony zwierząt, ochrona środowiska przed nadzwyczajnymi zagrożeniami).

Na podręcznik pod red. Jana Bocia (wyd. 2004) składa się 14 rozdziałów:

I. Z rozwoju koncepcji ochrony środowiska;

II. Podstawowe pojęcia;

III. Przesłanki ochrony środowiska;

IV. Prawnomiędzynarodowe aspekty ochrony środowiska;

V. Uwagi o polskim systemie regulacji prawnej ochrony środowiska;

VI. Determinacja pozaprawna;

VII. Z organizacji ochrony środowiska;

VIII. Administracyjnoprawne formy działań ochronnych;

IX. Podstawowe instytucje prawnej ochrony środowiska;

$\mathrm{X}$. Internalizacja kosztów zewnętrznych;

XI. Interes jednostki w prawie ochrony środowiska;

XII. Dostęp do informacji;

XIII. Odpowiedzialność prawna w ochronie środowiska;

XIV. Stan polityki w ochronie.

Opracowanie „łódzkie” składa się z dwóch zasadniczych części: pierwszej, zatytułowanej „Zagadnienia ogólne”, i drugiej - „Regulacje sektorowe”. Na część pierwszą składa się 5 rozdzialów, poświęconych kolejno zagadnieniom wprowadzającym, zasadom ogólnym prawa ochrony środowiska, zarządzaniu sprawami ochrony środowiska, instrumentom finansowo prawnym, odpowiedzialności prawnej w ochronie środowiska. Część druga to 9 rozdziałów: ochrona jakości środowiska i prawo emisyjne, ochrona powietrza, zapobieganie i usuwanie skutków poważ- 
nych awarii i postępowanie z substancjami chemicznymi, gospodarowanie odpadami, gospodarowanie wodami śródlądowymi, ochrona wód morskich, gospodarowanie zasobami geosfery, ochrona różnorodności biologicznej, ochrona użytkowa zasobów biosfery.

Błażej Wierzbowski i Bartosz Rakoczy opierają swoje Podstawy prawa ochrony środowiska ${ }^{22}$ na czterech częściach:

I. Wprowadzenie do prawa ochrony środowiska;

II. Podstawowe instytucje prawa ochrony środowiska;

III. Ochrona poszczególnych elementów środowiska;

IV. Gospodarowanie odpadami.

W części pierwszej omawiają zagadnienia wstępne - pojęcie środowiska i jego ochrony, pojęcia prawa ochrony środowiska i jego rozwój, źródła prawa ochrony środowiska, ochrona środowiska w prawie międzynarodowym i europejskim oraz zasady prawa ochrony środowiska. Część II to środki prawno-finansowe ochrony środowiska, odpowiedzialność w prawie ochrony środowiska i organy i instytucje ochrony środowiska. Część szczegółowa (trzecia) obejmuje ochronę środowiska w zagospodarowaniu przestrzennym i przy realizacji inwestycji, ochronę kopalin, wód, zwierząt i roślin, problematykę prawa emisyjnego oraz ochrony przyrody. Natomiast część czwarta poświęcona jest gospodarowaniu odpadami.

Na koniec chcemy wspomnieć o dwóch pozycjach, może nie podręcznikowych, ale z pewnością dydaktycznych. Są to Prawo ochrony środowiska. Konwersatoria ${ }^{23}$ oraz Prawo ochrony środowiska w kazusach, zebranych przez B. Rakoczego ${ }^{24}$. Pomysł Konwersatoriów opiera się na zebraniu podstawowych aktów prawnych z zakresu ochrony środowiska (zarówno krajowych jak i ponadkrajowych), bądź w całości bądź w najważniejszych fragmentach. Na koniec autorzy publikują kilkanaście testów sprawdzających znajomość przedrukowanych aktów normatywnych. Koncepcja kazusów zebranych przez B. Rakoczego to zary-

22 Wydanie I z 2004 r.

23 J. Boć, A. Chajbowicz, I. Białowąs, A. Haręża, Ł. Miłkowski, Wrocław 2009.

24 Toruń 2008. 
sowanie stanów faktycznych z różnych działów prawnej ochrony środowiska wraz z przedstawionym studentowi pytaniem, dotyczącym rozwiązania przedstawionego zagadnienia.

\section{CZECHOSŁOWACJA I REPUBLIKA CZESKA}

Początek zainteresowania problematyką prawną ochrony środowiska w byłej Czechosłowacji przypada, podobnie jak w innych państwach Europy i świata, na lata 70. XX wieku. Zaznaczył się on pojedynczymi artykułami i studiami w periodykach prawniczych, aby w czasem doprowadzić do pozycji książkowych. Najważniejsze w latach 70. i 80. ubiegłego stulecia pozycje wiążą się z nazwiskami Zdeňka Madara z Pragies, Boleslava Pospišila z Brna ${ }^{26}$ i Jozefa Klapača z Bratysławy ${ }^{27}$. Żadna z przywołanych książek nie miała jednak charakteru podręcznika.

Jak informuje Zdeněk Madar, zagadnienia prawne ochrony środowiska były najpierw wykładane na Wydziale Prawa Uniwersytetu Karola w Pradze w ramach prawa administracyjnego poczynając od $1968 \mathrm{r}$. W $1970 \mathrm{r}$. zostało do programu nauczania włączone seminarium (do wyboru) o zagadnieniach prawnych ochrony środowiska, a oddzielny wykład został do tego programu włączony w latach 70 . Na początku lat 80 . nauczanie prawa środowiska zostało uznane za samoistny wykład kończony egzaminem, ale w katedrze prawa rolniczych spółdzielni produkcyjnych, co autor ten ocenia jako nielogiczne ${ }^{28}$. W działalności publikacyjnej i pedagogicznej nie można było określać zagadnień prawnych środowiska nazwą prawa środowiska (pravo životniho prostredi), ponieważ cały ówczesny klimat nie sprzyjał powsta-

25 Z. Madar, Československe pravo, statni sprava a životni prostředi, Praha 1977; tenże Pravo socialistickych statů a peče o životni prostředi, Praha 1983.

26 B. Pospišil, Životni prostředi očima pravnika, Brno 1981.

27 J. Klapač, Pravo na životne prostredie a pravo životneho prostredia, Bratislava 1985.

28 Z. Madar, Vznik a vyvoj prava životniho prostredi $v$ Česke republice, [w:] Pravo a životni prostředi. Sbornik referatů z védecke konference, Praha 2003, s. 47. 
niu nowej dziedziny prawnej, tj. prawa środowiska. Dlatego tak w działalności naukowej, jak i dydaktycznej można było posługiwać się jedynie nazwą „zagadnienia prawne ochrony i tworzenia środowiska" (pravni otazky ochrany a tvorby životniho prostředi) ${ }^{29}$.

Te dwa pojęcia ochrony i tworzenia środowiska łączyły się zwykle w nadrzędną kategorię pieczy (troski) o środowisko peče o životni prostředi $\mathrm{w}$ języku czeski oraz starostlivost'o životne prostredie w języku słowackim. Pod takim też tytułem ukazało się jedno z pierwszych opracowań dydaktycznych na Uniwersytecie Karola w Pradze ${ }^{30}$.

Po „aksamitnej rewolucji” roku 1989 pierwsza fala legislacji w dziedzinie ochrony środowiska zaznaczyła się w latach 1991-1992, kiedy jeszcze w ramach Federacji Czesko-Słowackiej zostały wydane m.in. ustawy o odpadach, o ochronie powietrza, o ochronie gleb, o środowisku, o ochronie przyrody i krajobrazu. Podręcznika wtedy nie było, a jego rolę w pewnym zakresie pełniły trzy wydania $(1995,1997$ i 1999) zbioru przepisów opatrzonych komentarzami wprowadzającymi Jaroslava Drobnika i Milana Damohorskiego ${ }^{31}$. Jak oceniają kontynuatorzy tego dzieła, Martin Smolek i Tereza Ticha, w wydanym w latach 2002-2003 trzytomowym, liczącym łącznie 1071 stron zbiorze przepisów z komentarzami wprowadzającymi ${ }^{32}$, ten pierwszy zbiór zastępował w owym czasie podręcznik prawa środowiska. Aby zweryfikować ten pogląd spójrzmy na trzecie wydanie zbioru Jaroslava Drobnika i Milana Damohorskiego z 1999 r. Jak piszą autorzy we wstępie, celem tej publikacji nie było tylko zebranie tekstów podstawowych przepisów prawnych, które na poziomie ustawowym regulują problematykę ochrony środowiska, ale jednocześnie ich

29 Tamże.

30 V. Fabry, J. Drobnik, M. Hegenbart et al., Pravni aspekty peče o životni prostředi, Praha 1985.

31 J. Drobnik, M. Damohorsky, Zakony k ochraně životniho prostředi a predpisy souvisejici - Texty s uvodnimi komentaři, Nakladatelstvi C.H.Beck, 1. vydani Praha 1995, 2. vydani Praha 1997, 3. vydani Praha 1999.

32 M. Smolek, T. Ticha, Prameny prava životniho prostředi. Vyběr akualnich zněni zakonů s uvodnimi komentaři, 1. dil - Obecna čast, Praha 2002, 2. dil Zvlaštni čast I, Praha 2002, 3. dil - Zvlaštni čast II, Praha 2003. 
uporządkowanie w postaci pewnego systemu, tak aby czytelnik mógł lepiej orientować się w całej rozległości aktów prawnych $\mathrm{w}$ tej dziedzinie. Komentarze wprowadzające (uvodni komenta$\check{r}$ e) mają czytelnikom ułatwić właściwe zrozumienie podstawy i celu obowiązującej regulacji oraz wskazać na więzi wzajemne miedzy poszczególnymi ustawami.

W powoływanym dziele zarysował się już pewien schemat uporządkowania problematyki ochrony środowiska. Autorzy ujęli 25 ustaw w następującym układzie:

I. Podstawy prawne i podstawowe zasady prawa ochrony środowiska (6-stronicowy komentarz i teksty 4 ustaw: fragmenty Konstytucji i Karty Podstawowych Praw i Wolności, ustawa o środowisku, ustawa o prawie do informacji o środowisku).

II. Organizacja ochrony środowiska (4-stronicowy komentarz i teksty 5 ustaw: fragmenty ustawy o centralnych organach administracji, administracji powiatowej i gminnej, ustawa o Czeskiej Inspekcji Środowiska, ustawa o Państwowym Funduszu Środowiska).

III. Specyficzne środki ochrony środowiska (9-stronicowy komentarz oraz teksty 3 ustaw: budowlanej, o ocenach oddziaływania na środowisko oraz fragmenty ustawy o zdrowiu).

IV. Odpowiedzialność ekologiczno-prawna (4-stronicowy komentarz oraz fragmenty 3 ustaw: kodeksu karnego, ustawy o wykroczeniach, kodeksu cywilnego).

V. Ochrona komponentów środowiska i ekosystemów (31-stronicowy komentarz oraz teksty 8 ustaw: o ochronie powietrza, o administracji ochrony powietrza, o ochronie warstwy ozonowej, wodnej, o administracji wodnej, o ochronie zasobów gruntów rolnych, o lasach, o ochronie przyrody i krajobrazu).

VI. Ochrona przed szczególnymi źródłami zagrożenia środowiska (13-stronicowy komentarz oraz teksty 2 ustaw: o odpadach $i$ atomowej).

W dziele liczącym XIII + 451 stron komentarze wprowadzające zajmują 67 stron i zostały napisane w typowym podręcznikowym stylu z omówieniem m.in. źródeł, ich charakteru, podstaw, założeń wyjściowych, zasad prawa środowiska. 
Ten sposób prezentacji źródeł kontynuują Martin Smolek i Tereza Ticha także poprzedzając każdy z rozdziałów komentarzem wprowadzającym, ale dodatkowo wskazują na pozycje literatury, inne akty prawne związane z zamieszczonymi w zbiorze, źródła prawa międzynarodowego i unijnego oraz na odpowiednie strony internetowe.

Pierwszym podręcznikiem w pełnym tego słowa znaczeniu było trzytomowe dzieło pracowników naukowych Wydziału Prawa Uniwersytetu Masaryka w Brnie opracowywane w zmieniającym się składzie autorskim, którego trzon stanowili Milan Pekarek, Ivana Průchova, Ilona Jančařova i Jana Dudova, wcześniej uczestniczył także Józef Cingroš, później zaś doszła Jana Tkačikova ${ }^{33}$.

Następnym był podręcznik autorów związanych z Katedrą Prawa Środowiska Wydziału Prawa Uniwersytetu Karola w Pradze w składzie: Milan Damohorsky (koordynator całości i autor znaczących części dzieła), Jaroslav Drobnik, Martin Smolek, Michal Sobotka i Vojtěch Stejskal ${ }^{34}$.

Kierownik zespołu autorskiego, Milan Damohorsky, wydał również zwięzły dwujęzyczny (czesko-angielski) podręcznik czeskiego prawa środowiska w serii prezentującej prawo czeskie na tle prawa europejskiego ${ }^{35}$.

33 I. Jančařova, M. Pekarek, Pravo životniho prostředi. I. dil, Masarykova Univerzita, Brno 2002, drugie wydanie M. Pekarek, I. Průchova, J. Dudova, I. Jančařova, J. Tkačikova, Pravo životniho prostředi. I. dil, Masarykova Univerzita. Pravnicka Fakulta, Brno 2009; J. Cingroš, J. Dudova, I. Jančařova, M. Pekarek, I. Průchova, Pravo životniho prostředi. 2. dil, Masarykova Univerzita, Brno 1998, drugie wydanie J. Dudova, I. Jančařova, M. Pekarek, I. Průchova, Pravo životniho prostředi. 2. dil, Masarykova Univerzita. Pravnicka Fakulta. Edice učebnic č. 377, Brno 2006; J. Cingroš, J. Dudova, I. Jančařova, M. Pekarek, I. Průchova, Pravo životniho prostředi. 3. dil, Masarykova Univerzita, Brno 1998, drugie wydanie J. Dudova, I. Jančařova, M. Pekarek, I. Průchova, Pravo životniho prostředi, 3. dil, Masarykova Univerzita. Pravnicka Fakulta. Edice učebnic č. 390, Brno 2007.

34 Milan Damohorsky a kolektiv, Pravo životniho prostředi. Pravnicke učebnice, 1. vydani, C.H. Beck Praha 2003, 2. vydani, C.H. Beck Praha 2007, 3. vydani, C.H. Beck Praha 2010.

35 M. Damohorsky, Česke pravo životniho prostredi - Czech Environmental 2/2011 Law. Učebni pomůcka pro program Czech Legal System in European Context, Uni- 
Na uwagę zasługuje także wydany jako podręcznik Wstęp do prawa środowiska autorstwa Milana Kindla i Ondřeja Davida związanych z uniwersytetem w Pilznie ${ }^{36}$. Jest to podręcznik dość nietypowy, ponieważ obejmuje wyłącznie problematykę prawa prywatnego, podczas gdy powszechnie wiadomo, że prawo środowiska to domena prawa administracyjnego.

Wielce znaczące dla nauki i dydaktyki ochrony przyrody jest obszerne, liczące 590 stron, dzieło Vojtěcha Stejskala zatytułowane: Wstęp do regulacji prawnej ochrony przyrody $i$ troski o różnorodność biologicznq ${ }^{37}$. Zwróćmy uwagę na jego układ w czterech częściach:

I. Wprowadzenie do regulacji prawnej ochrony przyrody i troski o różnorodność biologiczną (s. 29-60);

II. Prawo międzynarodowe (s. 61-235);

III. Europejskie prawo wspólnotowe (s. 236-397);

IV. Prawo czeskie (s. 398-553).

Objawiło się $\mathrm{W}$ nim to nowoczesne ujęcie polegające na tym, że po teoretycznym wprowadzeniu następuje triada: prawo międzynarodowe - prawo unijne - prawo krajowe. Warto zwrócić uwagę, iż taką samą systematykę przyjęli w swoim podręczniku polscy autorzy J. Jendrośka i M. Bar.

Wprawdzie opracowanie Vojtěcha Stejskala nie jest podręcznikiem prawa środowiska, ale merytorycznie jest podręcznikiem prawa ochrony przyrody.

Na podręcznikach nie kończą się opracowania mające charakter dydaktyczny. Mamy tu na uwadze Zbiór praktycznych przykładów z prawa środowiska autorstwa pracowników naukowych Katedry Prawa Środowiska Wydziału Prawa Uniwersytetu Karola w Pradze: w wydaniu pierwszym Milana Damohorskiego, Jaroslava Drobnika, Michala Sobotki i Vojtěcha Stejskala ${ }^{38}$,

verzita Karlova v Praze. Pravnicka fakulta 2003, drugie wydanie 2006.

36 M. Kindl, O. David, Pravnicke učebnice. Uvod do prava životniho prostredi. Soukromopravni aspekty ochrany životniho prostředi, Vydavatelstvi a nakladatelstvi Aleš Čeněk, s.r. o., Plzeń 2005.

37 V. Stejskal, Uvod do pravni upravy ochrany prrirody a peče o biologickou rozmanitost, Praha 2006.

38 M. Damohorsky, J. Drobnik, M. Sobotka, V. Stejskal, Sbirka praktickych přikladi̊ z prava životniho prostředi, ASPI Publishing, Praha 2004. 
w wydaniu drugim poszerzonym o autorstwo Martiny Frankovej i Karoliny Žakovskiej ${ }^{39}$.

Nieco inny charakter ma Zbiór przykładów i orzeczeń dotyczacych prawa środowiska autorstwa związanych z Uniwersytetem Masaryka w Brnie Jana Bahyl'a, Lenki Bahyl'ovej i Tomaša Kocourka ${ }^{40}$.

Zwróćmy wreszcie uwagę na praktyczny przewodnik po prawie środowiska Unii Europejskiej autorstwa Evy Kružikovej, Evy Adamovej i Jana Komarka ${ }^{41}$ kierowany przez autorów przede wszystkim do studentów szkół wyższych, zwłaszcza wydziałów prawa. W zwięzłej formie, w podziale (poprzedzonym charakterystyką Unii Europejskiej i unijnego prawa środowiska) na przepisy horyzontalne i szczególne prezentuje podstawowe akty unijne oraz omówienie najważniejszych orzeczeń Europejskiego Trybunału Sprawiedliwości.

Przechodząc do rozważań merytorycznych spójrzmy na koncepcję dydaktyczną prezentowaną $\mathrm{w}$ podręcznikach czeskich, zaczynając od starszego podręcznika brneńskiego w aktualnych wydaniach. Część pierwsza licząca 323 strony składa się z dziewięciu następujących rozdziałów: I. Pojęcia podstawowe; II. Prawo a środowisko, prawo środowiska; III. Zasady prawa środowiska; IV. Instytucjonalne zapewnienie ochrony środowiska oraz podmioty prawa środowiska; V. Formy działania administracji publicznej w dziedzinie ochrony środowiska; VI. Udostępnianie informacji o środowisku; VII. Prewencja w prawie środowiska; VIII. Odpowiedzialność w prawie środowiska; IX. Własność, przedsiębiorczość a środowisko. Część druga licząca 379 stron składa się z jedenastu następujących rozdziałów:

I. Prawny reżim ochrony powietrza;

II. Prawny reżim ochrony wód;

III. Prawny reżim ochrony gleb;

39 Milan Damohorsky a kolektiv, Sbirka praktickych přikladů z prava životniho prostredi, 2., aktualizovane vydani, Wolters Kluwer ČR, Praha 2010.

40 J. Bahyl', L. Bahyl'ova, T. Kocourek, Přiklady a judikatura z prava šivotniho prostředi, Nakladatelstvi Leges, s.r. o., Edice Student, Praha 2010.

41 E. Kružikova, E. Adamova, J. Komarek, Pravo životniho prostředi Evropskych společenstvi. Prakticky průvodce, Praha 2003. 
IV. Prawny reżim ochrony przyrody i krajobrazu;

V. Ochrona gatunków dziko żyjących zwierząt i dziko rosnących roślin w ramach handlu międzynarodowego;

VI. Prawny reżim ochrony zwierząt przed znęcaniem się nad nimi;

VII. Prawny reżim łowiectwa;

VIII. Prawna ochrona ryb, gospodarki stawowej i wykonywania prawa rybackiego;

IX. Prawny reżim ochrony pszczół;

X. Prawna ochrona lasów;

XI. Prawny reżim ochrony zabytków kultury.

Część trzecia licząca 327 stron składa się z siedmiu następujących rozdziałów:

1. Regulacja prawna postępowania z odpadami,

2. Ochrona środowiska przy postępowaniu z substancjami chemicznymi,

3. Ochrona środowiska i zdrowia przed niepożądanymi skutkami promieniowania jonizującego i energii jądrowej,

4. Ochrona środowiska przy zagospodarowywaniu powierzchni ziemi,

5. Ochrona środowiska w rolnictwie,

6. Ochrona środowiska przy wykorzystywaniu zasobów kopalnych,

7. Zdrowe warunki życia.

Trzy części podręcznika brneńskiego liczą łącznie 1029 stron. Podział materii między częściami jest klarowny: część pierwsza to zagadnienia ogólne, część druga to ochrona komponentów środowiska, część trzecia to ochrona przed oddziaływaniami na środowisko. Istotne w podręczniku brneńskim jest wyodrębnienie ochrony pszczół oraz ujęcie w samodzielnym rozdziale ochrony zabytków kultury, którą autorzy czescy (a także słowaccy) zaliczają do dziedziny ochrony środowiska.

Koncepcja podręcznika praskiego jest nieco odmienna od brneńskiego. Zespół autorski kierowany przez Milana Damohorskiego w jednotomowym dziele liczącym w ostatnim wydaniu 629 stron przyjął podział na cześć ogólną i szczególną. Na część ogólną prawa środowiska składa się pięć rozdziałów:

I. Podstawy ochrony środowiska; 
II. Prawo środowiska (uwagi wprowadzające i rozwój historyczny, przedmiot i system, źródła, instrumenty ochronne, podstawy konstytucyjne, zasady podstawowe, ochrona środowiska i własność);

III. Organizacja ochrony środowiska;

IV. Odpowiedzialność prawna w ochronie środowiska;

V. Ochrona środowiska w prawie międzynarodowym i unijnym. Część szczególna została ujęta w kolejnych czterech rozdziałach;

VI. Środki ochrony środowiska (planowanie przestrzenne, oceny oddziaływania na środowisko, zintegrowana prewencja i obniżanie poziomu zanieczyszczenia, informacja i uczestnictwo społeczeństwa w ochronie środowiska);

VII. Ochrona komponentów środowiska i ekosystemów (powietrza i warstwy ozonowej Ziemi, wody, gleby, lasu, przyrody i krajobrazu, świata roślinnego i zwierzęcego);

VIII. Ochrona przed źródłami zagrożenia środowiska (odpady i opakowania, promieniowanie, hałas i wibracje, organizmy genetycznie zmodyfikowane, substancje i preparaty chemiczne, klęski żywiołowe);

IX. Regulacja prawna ochrony środowiska w ramach innych działalności ludzi (ochrona zdrowia, troska o zabytki kultury, górnictwo, rolnictwo, energetyka, komunikacja).

Różnica między ujęciem brneńskim i praskim polega m.in. na tym, że tzw. horyzontalne instrumenty ochrony środowiska autorzy brneńscy zaliczają do części ogólnej, autorzy czescy do szczególnej.

Zwraca uwagę podejście autorów praskich do międzynarodowego i unijnego prawa środowiska. Poświęcają temu odrębny rozdział V podręcznika liczący 104 strony (1/6 całości), ale te rozważania pojawiają się także w kolejnych rozdziałach składających się na część szczególną. Posłużymy się przykładem oddziału 5 „Ochrona przyrody i krajobrazu” autorstwa Vojtěcha Stejskala w rozdziale VII. Konstrukcja oddziału 5 jest następująca: 5.1. Przyczyny, cel i rozwój regulacji prawnej (s. 338-341), 5.2. Dokumenty prawnomiędzynarodowe (s. 341-357), 5.3. Regulacja prawna w Unii Europejskiej (s. 357-363), 5.4. Źródła 2/2011 regulacji prawnej w Republice Czeskiej (s. 362-363), 5.5. Przed- 
miot, środki i główne kierunki regulacji prawnej (s. 363-396), 5.6. Organizacja ochrony przyrody (s. 396-397). Jest to znany już z innych prac tego autora podział materii według triady: prawo międzynarodowe - prawo unijne - prawo czeskie, ale prowadzony w ramach rozdziału części szczególnej podręcznika.

Rozważania nad dydaktyką prawa środowiska w Republice Czeskiej zakończymy zwięzłą prezentacją dwóch zbiorów przykładów, zaczynając od liczącego 225 stron zbioru autorstwa pracowników Katedry Prawa Środowiska Wydziału Prawa Uniwersytetu Karola w Pradze. W drugim wydaniu z 2010 r. autorzy przyjęli następujący układ:

I. Zasady, pojęcia i założenia prawa środowiska;

II. Organy ochrony środowiska i ich kompetencje;

III. Prawo do informacji o środowisku;

IV. Udział społeczeństwa w ochronie środowiska;

V. Odpowiedzialność prawna w ochronie środowiska;

VI. Instrumenty horyzontalne ochrony środowiska:

A. Planowanie przestrzenne;

B. Oceny oddziaływania na środowisko;

C. Zintegrowana prewencja i kontrola zanieczyszczeń;

VII. Ochrona powietrza;

VIII. Ochrona wód;

IX. Ochrona gleby;

X. Ochrona lasu;

XI. Ochrona przyrody i krajobrazu;

XII. Ochrona roślin i zwierząt;

XIII. Postępowanie z odpadami i opakowaniami;

XIV. Ochrona przed pozostałymi źródłami zagrożenia środowiska (promieniowanie, hałas i wibracje, organizmy genetycznie zmodyfikowane, substancje i preparaty chemiczne, awarie, klęski żywiołowe).

Każdy rozdział (a w rozdziale VI podrozdział) ma identyczną konstrukcję. Po kilkunastu pytaniach kontrolnych autor rozdziału wskazuje na odnośne przepisy prawne (zawsze czeskie, a jak trzeba to także międzynarodowe i unijne), po czym następuje kilka przykładów praktycznych (łącznie w dziele znajduje się 98 przykładów) z reguły inspirowanych konkretnymi sprawami oraz po kilka pytań do każdego przykładu, rozdział kończy 
się wskazaniem na wybrane orzecznictwo sądów (czeskich, a jak trzeba także międzynarodowych i unijnych). Po tych czternastu rozdziałach następuje wykaz wykorzystanej i zalecanej literatury (61 pozycji, ale w ogóle jest ich więcej, ponieważ w poszczególnych rozdziałach autorzy wskazują i na inne nieujęte w wykazie ogólnym) oraz wskazanie na 19 źródeł internetowych. Dzieło kończy opracowany przez Milana Damohorskiego na 175-223 Słowniczek podstawowych pojęć z dziedziny prawa środowiska zawierający zwięzłe zdefiniowanie 302 pojęć od autovraku (na potrzeby gospodarowania odpadami) do životniho prostredi (w brzmieniu definicji ustawowej).

Dla zilustrowania koncepcji dydaktycznej autorów zbioru posłużymy się dwoma przykładami. Z rozdziału I autorstwa Milana Damohorskiego wybieramy przykład nr 3. Miasto czeskie posiadające statut (a tym samym osobowość prawną) wystąpiło do sądu z powództwem przeciwko Republice Czeskiej zarzucając naruszenie podstawowego prawa do środowiska z art. 35 ust. 1 Karty Podstawowych Praw i Wolności będącej częścią konstytucyjnego porządku Republiki Czeskiej ${ }^{42}$. Miasto zarzuca, że państwo toleruje przekraczanie standardów imisyjnych i emisyjnych, dalej miasto przedstawia opinie z dziedziny ochrony zdrowia, higieny, meteorologii i ochrony środowiska, domagając się podjęcia przez państwo konkretnych przedsięwzięć zmierzających do zachowania standardów. Na tle tego przykładu autor stawia studentowi cztery pytania:

- oceń szanse miasta na sukces w postępowaniu przed sądem,

- przeanalizuj tę sprawę przy założeniu, że z powództwem występuje burmistrz miasta jako prywatna osoba fizyczna,

- jakimi innymi niż sądowe środkami można domagać się realizacji prawa do środowiska?

- jakie przepisy prawa międzynarodowego i unijnego obowiązują bezpośrednio w Republice Czeskiej i jakie to ma znaczenie?

${ }^{42}$ Ten art. 35 w ust. 1 stanowi: Každy ma pravo na přiznive životni prostředi (Każdy ma prawo do korzystnego/sprzyjającego/ środowiska). 
Drugi przykład zaczerpniemy z rozdziału XIV w opracowaniu Karoliny Žakovskiej. Przykład nr 1 podaje, że spółka została ukarana przez Czeską Inspekcję Środowiska karą pieniężną za uprawianie bez pozwolenia genetycznie zmodyfikowanej kukurydzy. Spółka wniosła odwołanie argumentując, że zgodnie z ustawą zawiadomiła Ministerstwo Środowiska o zamiarze uprawy kukurydzy genetycznie zmodyfikowanej i po zawiadomieniu rozpoczęła jej uprawę. Ministerstwo oddaliło odwołanie i utrzymało w mocy decyzję karną. Na tle tego przykładu autorka stawia studentowi pięć pytań:

- czy spółka musiała mieć pozwolenie, czy wystarczyło zawiadomienie?

- czy organy administracji działały prawidłowo?

- czy Inspekcja mogła zobowiązać spółkę do likwidacji uprawy?

- co by się zmieniło, gdyby uprawę prowadziła osoba fizyczna niebędąca przedsiębiorcą?

- jakie mogłoby mieć znaczenie to, gdyby chodziło o organizm genetycznie zmodyfikowany zapisany do rejestru warunkującego wprowadzenie go do obrotu?

Nieco inny jest zbiór autorów współpracujących z Katedrą Prawa Środowiska i Prawa Gruntowego Wydziału Prawa Uniwersytetu Masaryka w Brnie. Dzieło liczące 208 stron zostało podzielone na dwanaście rozdziałów (rozdziały 1-6 obejmują zagadnienia części ogólnej, rozdziały 7-12 części szczególnej):

1. Pojęcia podstawowe, umocowanie konstytucyjne i organizacja;

2. Prawo do informacji o środowisku;

3. Udział społeczeństwa w ochronie środowiska;

4. Oceny oddziaływania na środowisko;

5. Pozostałe horyzontalne instrumenty ochrony środowiska (zintegrowana kontrola zanieczyszczeń, postępowania prowadzone na podstawie ustawy budowlanej);

6. Odpowiedzialność prawna w ochronie środowiska;

7. Ochrona powietrza;

8. Ochrona wód;

9. Ochrona lasu i gleby; 
10. Ochrona przyrody i krajobrazu;

11. Postępowanie z odpadami i opakowaniami;

12. Ochrona przed innymi źródłami zagrożeniami środowiska.

Każdy rozdział zaczyna się od kilkunastu pytań o charakterze sprawdzającym, po czym następują przykłady i pytania do przykładów. Łącznie w dziele znajduje się 87 przykładów. Autorzy nie wskazują na źródła ani literaturę, lecz po przykładach następują tylko fragmenty orzeczeń sądowych. Jest ich łącznie 230 z reguły na kilkunastu linijkach, wyjątkowo fragmenty orzeczeń przekraczają stronę. Podliczenie wykazuje, że są to fragmenty zaczerpnięte $\mathrm{z}$ orzecznictwa:

- Europejskiego Trybunału Sprawiedliwości - 20,

- Europejskiego Trybunału Praw Człowieka - 1,

- Sądu Konstytucyjnego - 27,

- Sądu Najwyższego - 24,

- Najwyższego Sądu Administracyjnego - 133,

- sądów niższych instancji- 25.

Aby zilustrować koncepcję dydaktyczną posłużymy się przykładem 6 z rozdziału 10 „Ochrona przyrody i krajobrazu". Pan Okoun ma mały staw, w którym hoduje ryby, przede wszystkim karpie i pstrągi. Większą część ryb w roku poprzednim zeżarły kormorany, wobec czego pan Okoun zdecydował, aby na brzegach stawu umieścić urządzenia płoszące, co do których wiadomo, że przy kontakcie z nimi mogą poważnie poranić ptaki, co też się stało. Na tle tego przykładu autorzy postawili studentowi dwa pytania:

- czy pan Okoun naruszył swoim zachowaniem warunki ochrony zwierząt? Swoją odpowiedź uzasadnij konkretnymi przepisami ustawy,

- pan Okoun szuka adwokata, aby się poradzić, czy ma roszczenie o odszkodowanie za straty spowodowane w hodowli ryb. Jakie postępowanie doradziłbyś panu Okounowi?

Szerokie uwzględnienie orzecznictwa odróżnia to dzieło od zbioru praskiego, co zresztą nie oznacza, aby autorzy prascy nie pokusili się o prezentację orzecznictwa. Obszerny prze2/2011 gląd judykatury obejmujący nie tylko orzeczenia sądowe, ale 
i stanowiska organów administracji, ukazał się przed kilkoma laty w opracowaniu Veroniki Langrovej ${ }^{43}$, aczkolwiek ten przegląd obejmuje stan na 31 grudnia 2006 r., podczas gdy autorzy związani z Uniwersytetem Masaryka zamieścili w swoim zbiorze przede wszystkim najnowsze orzeczenia sądów międzynarodowych i sądów czeskich.

\section{SŁOWACJA}

Słowacka literatura podręcznikowa jest uboższa od czeskiej. Z lat 90. ubiegłego stulecia odnotować należy przede wszystkim cztery pozycje o tym charakterze wydane przez wydziały prawa uniwersytetów w Bratysławie ${ }^{44}$ i Koszycach ${ }^{45}$. Po nich pojawił się u progu XXI wieku wspólny podręcznik autorów słowackich Milana Štefanoviča, Soni Košičiarovej i Jana Pirča ${ }^{46}$, a po roku dwutomowe dzieło napisane przez prawników nie tylko słowackich, ale także czeskich, pod redakcją Soni Košičiarovej" ${ }^{47}$ Kontynuacją tego podręcznika było Pravo životneho prostredia, tejże Soni Košičiarovej z zespołem, którego pierwsze wydanie ukazało się w 2006 r. ${ }^{48}$, drugie w 2009 r. ${ }^{49}$ Dodać tu jeszcze trzeba anglo-

43 V. Langrova, Přehled judikatury z oblasti životniho prostředi, ASPI Praha 2007, s. 380 .

44 S. Košičiarova a kolektiv, Pravo životneho prostredia, Bratislava 1995, oraz Pravo životneho prostredia europskych krajin, Bratislava 1997.

45 J. Pirč, Zaklady prava životneho prostredia, Košice 1996 oraz Ochrana životneho prostredia v europskom prave, Košice 1998.

46 M. Štefanovič, S. Košičiarova, J. Pirč, Pravo životneho prostredia, Iura Edition - Edicia Učebnice, Bratislava 2001, s. 254.

47 S. Košičiarova a kolektiv, Pravo životneho prostredia. Všeobecna čast'. 1. čast', Edicia Učebnice, Heureka, Šamorin 2002, s. 375 oraz Pravo životneho prostredia. Osobitna čast'. 2. čast', Edicia Učebnice, Heureka, Šamorin 2002, s. 239.

48 S. Košičiarova a kolektiv, Pravo životneho prostredia, Bratislavska vysoka škola prava, Bratislava 2006, s. 464.

49 S. Košičiarova a kolektiv, Pravo životneho prostredia, 2. zmenene a rozširene vydanie, Bratislavska vysoka škola prava, Bratislava 2009, s. 680. 
języczny podręcznik europejskiego prawa środowiska autorstwa Soni Košičiarovej ${ }^{50}$.

Zatrzymamy się nad aktualnym wydaniem podstawowego podręcznika słowackiego. 23-osobowy zespół autorski z trzech państw: Gerard Loibl z Niemiec (autor fragmentu poświęconego zasadom międzynarodowego i europejskiego prawa środowiska), Milan Damohorsky, Veronika Langrova, Milan Pekarek, Jana Dudova, Ilona Jančařova, Vojtěch Stejskal i Ondřej Vicha z Republiki Czeskiej, Soňa Košičiarova (koordynatorka całości i autorka najistotniejszych części podręcznika), L’udmila Gajdošikova, Jozefina Machajova, Alena Pauličkova, Vladimir Pirošik, Martin Piry, Peter Sepeši, Jan Svak, Marian Ševčik, Milan Stefanovič, Štefan Uradniček, Martin Fadrny, Silvia Fajtakova, Zuzana Pištekova i Vladimir Hutta z Republiki Słowackiej - podzielił rozważaną materię na dwie części: ogólną i szczególną. Część ogólna prawa środowiska obejmuje siedem rozdziałów:

I. Regulacja prawna troski o środowisko (przedmiot i cel, zasady, system, charakter regulacji prawnej);

II. Źródła regulacji prawnej troski o środowisko (rodzaje, konstytucja, ustawy);

III. Działania rozstrzygające w zakresie troski o środowisko (administracja państwowa, samorząd terytorialny, sądy, Sąd Konstytucyjny Republiki Słowackiej);

IV. Pozycja osób fizycznych i prawnych w dziedzinie troski o środowisko (przedsiębiorca, właściciel, mieszkaniec gminy i okręgu samorządowego, stowarzyszenia, publiczność);

V. Podstawowe instytucje prawne troski o środowisko (planowanie przestrzenne, oceny oddziaływania na środowisko, zintegrowana prewencja i kontrola zanieczyszczeń, informacja o środowisku, zarządzanie środowiskowe i audyt, znakowanie środowiskowe);

VI. Odpowiedzialność w ochronie środowiska (podstawy i rodzaje, odpowiedzialność karna, odpowiedzialność administracyjna /za wykroczenia i inne delikty administracyjne/, odpowiedzialność za szkodę w środowisku, odpowiedzial-

50 S. Košičiarova, EC Environmental Law, Vydavatelstvi a nakladatelstvi Aleš Čeněk, s.r. o., Plzeň 2009, s. 223. 
ność za stare obciążenia środowiskowe, odpowiedzialność cywilna);

VII. Środki ekonomiczne i finansowe troski o środowisko.

Na część szczególną w koncepcji podręcznika słowackiego składają się cztery rozdziały:

I. Regulacja prawna troski o komponenty środowiska, zabytki kultury i ekosystemy (ochrona przyrody i krajobrazu, troska o nieruchome zabytki kultury, ochrona powietrza i warstwy ozonowej Ziemi, troska o wody oraz naturalne źródła lecznicze i mineralne, troska o glebę i rolnictwo ekologiczne, troska o lasy, roślinność, świat zwierzęcy i zasoby kopalne);

II. Regulacja prawna ochrony środowiska przez zagrożeniem i uszkodzeniem (postępowanie z odpadami, substancjami i preparatami chemicznymi, pokojowe wykorzystanie energii atomowej, ochrona przed awariami przemysłowymi, wykorzystywanie technologii genetycznych i genetycznie zmodyfikowanych organizmów, ochrona przed hałasem);

III. Bezpieczeństwo budów i produktów (bezpieczeństwo budów, techniczne wymagania odnoszące się do wyrobów, wymagania dotyczące wyrobów według przepisów szczególnych: paliwa, pasze, leki i preparaty weterynaryjne, opakowania);

IV. Ochrona zdrowia a środowisko.

Cechą charakterystyczną podręcznika słowackiego jest bardzo szerokie operowanie przykładami praktycznymi, ilustrowanie rozważań teoretycznych fragmentami aktów normatywnych wydawanych przez organy administracji terenowe czy też fragmentami decyzji administracyjnych. Jak pisze Soňa Košičiarova we wstępie, drugie wydanie podręcznika wspiera nowy trend nauczania na wydziałach prawa - odstąpienie od podręczników mających charakter dzieł naukowych i przychylenie się do zwięzłości i zrozumiałości wykładu. Celem jest nie tylko informować, ale i zainteresować oraz wywołać dyskusję, temu celowi służy opracowanie kazusów, którymi posługują się autorzy podręcznika. 


\section{PODSUMOWANIE}

Podstawą dydaktyki danej gałęzi prawa są zwykle najważniejsze akty normatywne oraz wybrane pozycje z literatury, najczęściej umownie zwane podręcznikami. Podręcznik to książka przeznaczona do nauki, zawierająca zbiór podstawowych wiadomości z jakiejś dziedziny (cytujemy za słownikiem języka polskiego). Dobremu nauczaniu prawa służą, co oczywiste, także inne źródła: komentarze, monografie, artykuły naukowe, glosy do orzeczeń sądowych, przykłady z praktyki. Jednak to podręcznik stanowi zwykle podstawę, elementarz, kompendium, to, co w średniowieczu określano jako summa. To podręcznik ma skupiać i łączyć w sobie wszystko, co w danej dziedzinie prawa (wiedzy) najistotniejsze. Rozumienie tego, co najważniejsze (najbardziej istotne) czyli dobór treści podręcznika zwykle będzie, oczywiście w pewnych granicach, indywidualną decyzją autora. Dlatego właśnie zdecydowaliśmy się na tego rodzaju przegląd - aby spróbować odnaleźć jakiś wspólny mianownik, wypośrodkować treści w ramach prawa ochrony środowiska wykładane. Można zauważyć, iż z reguły podręczniki opracowane są według następującego schematu: część ogólna - część szczegółowa. Część ogólna obejmuje zwykle objaśnienie pojęć i konstrukcji prawnych właściwych dla całości tej dziedziny prawa. Część szczegółowa to sposoby ochrony poszczególnych komponentów środowiska jak i ochrona przed określonymi oddziaływaniami na środowisko. Odniesienie do prawa ponadkrajowego (międzynarodowego i unijnego) następuje albo poprzez wyodrębnienie temu poświęconych działów (działu) albo poprzez łączne omawianie regulacji krajowej i ponadkrajowej w ramach konkretnych rozwiązań prawnych.

Prawo ochrony środowiska można określić jako kompleksową dziedzinę prawa, łączącą w sobie normy prawne o charakterze administracyjnym, karnym, konstytucyjnym, cywilnym i finansowym, aczkolwiek przeważają i podstawową rolę odgrywają regulacje o charakterze administracyjnoprawnym. Ten zróżnicowany charakter norm prawnych, rozległy obszar 2/2011 legislacji, liczne związki z prawem ponadkrajowym a także wy- 
stępowanie pewnych specyficznych dla prawa ochrony środowiska instrumentów powoduje, że dydaktyka prawa ochrony środowiska jest trudna. Wymaga od studiującego solidnych podstaw wiedzy prawniczej, ze szczególnym uwzględnieniem prawa administracyjnego, ogólnego i procesowego. Z tych względów nauczanie prawa ochrony środowiska $\mathrm{w}$ ramach studiów prawniczych nie powinno mieć miejsca zbyt wcześnie. Rzeczą podstawową i wyjściową jest to, aby słuchacz dobrze zrozumiał cel, przedmiot i miejsce prawa ochrony środowiska $\mathrm{w}$ ramach systemu prawa.

Nie bez racji końcem XIX w. Rudolf Ihering opatrzył swoje dzieło mottem: „Cel jest twórcą całego prawa"51. Wywodził, że dla rozumienia prawa należy zawsze zadać pytanie o cel normy prawnej, każda bowiem norma prawna jest efektem jakiejś potrzeby społecznej, jakiegoś celu. Jaki jest cel prawa ochrony środowiska? Odpowiedź zawartą w nazwie tej dziedziny prawa trzeba rozwinąć i podkreślić, że obowiązujące prawo ochrony środowiska za punkt wyjścia i dojścia ma człowieka i jego interesy, ma za swój przedmiot zachowania człowieka powstające w toku jego działalności, przede wszystkim gospodarczej. To człowiek decyduje o potrzebie ochrony środowiska i o jej zakresie. W związku z tym na pytanie komu ma służyć ochrona środowiska: czy ma służyć człowiekowi żyjącemu w środowisku czy też środowisku pojmowanemu jako nadrzędna wartość, odpowiadamy, że prawnie powinniśmy chronić środowisko przede wszystkim ze względu na potrzeby człowieka czyniąc wyjątek dla niektórych rozwiązań w zakresie ochrony przyrody (np. parki narodowe). Należy także uwypuklić, że prawo ochrony środowiska nie jest prawem, które chroni tylko jeden interes - ochronę środowiska. Prawo ochrony środowiska uwzględniać musi także inne interesy, które znalazły wyraz w regulacji konstytucyjnej, a w szczególności zostały zawarte w katalogu praw i wolności człowieka ${ }^{52}$. Od uświadomienia słuchaczom takiego celu i przedmiotu należałoby rozpoczynać wykład prawa ochrony środowiska.

51 R. Ihering, Der Zweck im Recht, Lipsk 1893.

52 J. Sommer, Efektywność prawa...., s. 8, 118-119. 
Nie mamy zamiaru, bo nie jest to celem niniejszego opracowania, choćby szkicować szczegółowego programu nauczania prawa ochrony środowiska. Chcemy jedynie, opierając się na dostępnych pozycjach podręcznikowych, pokazać, jak się tej dziedziny uczy. Nie tylko w Polsce ale także w Czechach i na Słowacji.

\section{BIBLIOGRAFIA}

Bar M., Jendrośka J., Prawo ochrony środowiska. Podręcznik, Wrocław 2005.

Boć J., Nowacki K., Samborska - Boć E., Ochrona środowiska, Wrocław 2004.

Brodecki Z. (red.), Ochrona środowiska. Acquis communataire, Warszawa 2005.

Bukowski Z., Podstawy prawa ochrony środowiska dla administracji, Włocławek 2005.

Ciechanowicz - McLean J.(red.), Polskie prawo ochrony przyrody, Warszawa 2006

Damohorsky M. a kolektiv, Pravo životniho prostředi. Pravnicke učebnice, Praha 2010

Górka K., Poskrobko B., Radecki W., Ochrona środowiska. Problemy spoleczne, ekonomiczne i prawne, Warszawa 2001.

Górski M.(red.), Prawo ochrony środowiska, Warszawa 2009.

Habuda A., Radecki W., Stan polskiej nauki prawa ochrony środowiska w 40 lat po raporcie U Thanta, „Studia Prawnicze” 2009, nr 3.

Košičiarova S. a kolektiv, Pravo životneho prostredia, Bratislava 2009. Lipiński A., Prawne podstawy ochrony środowiska, Warszawa 2010,

Paczuski R., Ochrona środowiska. Zarys wykładu, Bydgoszcz 2008.

Pekarek M., Jančařova I., Tkačikova J., Průchova I., Dudova J. Pravo životniho prostředi, Brno 2009.

Sommer J., Efektywność prawa ochrony środowiska i jej uwarunkowania - problemy udatności jego struktury, Wrocław 2005.

Stejskal V., Uvod do pravni upravy ochrany přirody a peče o biologickou rozmanitost, Praha 2006.

Stelmasiak J. (red.), Prawo ochrony środowiska, Lublin 2010. 
Szymańska U., Zębek E., Prawo i ochrona środowiska - prawne, ekonomiczne, ekologiczne i techniczne aspekty ochrony środowiska naturalnego, Olsztyn 2008.

Wierzbowski B., Rakoczy B., Podstawy prawa ochrony środowiska, Warszawa 2010.

Kontakt e-mail:

Adam Habuda: adh@interia.pl 